MAtgORZATA ABASSY ${ }^{1}$

\title{
THE CONCEPTION OF CULTURE, VALUES AND IDENTITY OF IRAN IN SHAYKH FAZLALLAH NURI'S WRITINGS
}

\begin{abstract}
The aim of this analysis of Nuri's writings is the creation of a model of culture which is based on the semantics of the notions qanun, eslam, mosvat, horriyat, mashrute/mashru'e, qanun-e asasi. Investigations into the model of culture proposed by Nuri will allow us to distinguish its specific features and to discover its roots and condition at the time of confrontation with an alternative model. The word qanun 'law' is the central one in Nuri's texts of the mashrute period. The history of its semantic transformation has its roots in the 1850s and the first contacts of the Iranian people with the West. Nuri inquired as to the semantics of the notions of qanun, mosavat, horriyat (azadi) and mashrute in discussions during the time of bast in Abdolazim mosque and in the conversations with representatives of the British embassy. He acted against these elements of law. He regarded himself as a religious leader for his community which, as a whole, constituted God's people whose final purpose was salvation.
\end{abstract}

Key words: Islam, Constitutional Revolution, Iran, Nuri Fazlallah

\section{ANALYTICAL MATERIAL}

The letters, telegrams, fatwas and other writings of Shaykh Fazlallah Nuri were produced within the period 1905-1909, and were gathered into two volumes by Mohammad Torkeman. Some texts are evidence of Nuri's attitude towards the problems he discussed, whereas others are a kind of appeal presented to various members of his readership, such as Mozaffar ad-Din Shah, state officials, representatives of foreign countries in Iran and

\footnotetext{
${ }^{1}$ Assoc. Prof.; Jagiellonian University in Kraków; malgorzata.abassy@uj.edu.pl.
} 
Shia clergymen. The collection of writings also contains some texts that were signed by a larger group of clergymen who shared Nuri's opinion. The uniqueness of Nuri's output, as a whole, is the fact that his thoughts do not evolve. There are some initial statements which are repeated many times, in many different ways. The Qur'an and hadiths are their main sources. This cognitive mechanism is in full accordance with such a culture in which "the Truth" is believed to exist in texts and can be discovered by exploring them. ${ }^{2}$ Nuri did not come up with any new findings within the field of the Islamic culture, and only articulated them when he was forced by circumstances to do so.

\section{THE RESEARCH PROBLEM}

The aim of this analysis of Nuri's writings is the creation of a model of the culture which is based on the semantics of the notions of qanun, eslam, mosavat, horriyat, mashrute/mashru'e, qanun-e asasi. A statement made by the Russian linguist, Victor Vinogradov is the point of departure for further analyses of Nuri's ideas. Vinogradov stressed the significance of certain words in a specific historical time by saying:

In some semantic groups, the most significant individual words occur as semantic centres, around which whole series of words and notions gather. When this conglomeration of words attracts new series of notions, its old meanings change. Such central words are rather like "suns" for separate semantic systems; they sometimes express the basic "battle cries" of this or another epoch. ${ }^{3}$

${ }^{2}$ There is a connection between a type of culture and the significance of texts within it. Textual culture preserves a stable hierarchy of texts left by ancestors; the Truth was fully revealed and its meaning rendered to the initiated, the guards of tradition. Functional culture (which occurred in Europe after the Industrial Revolution) is opposite, it "reduces the text to its literal meaning and regards itself as that which has been in existence since 'zero' and is collecting moments of truth; it is a culture inclined towards the future, wherein it will achieve its completeness." Comp. K. Rosner, Semiotyka strukturalna w badaniach nad literatura, Kraków 1981, p. 210.

${ }^{3} \mathrm{~V}$. Vinogradov, Istoria slov, http://etymolog.ruslang.ru/index.php?act=contents\& book=vinogradov, 30 November 2012 (headword: progress, trans. by M. Abassy). 


\section{THE GROUNDS FOR THE RESEARCH}

The period of the Persian Constitutional Revolution (1905-1911) was a time during which, in Iran, different conceptions of reality vied for supremacy. They were constructed on the basis of the same words but with different semantic interpretations of these words. Investigations into the model of culture proposed by Nuri will allow us to distinguish its specific features and to discover its roots and condition at the time of confrontation with an alternative model - that of the West.

The first phase of the mashrute (1905-1909) was shadowed with the slogan of a common struggle for social justice and independence of Iran from a foreign supremacy. Fazlallah Nuri, together with two other clergymen, Abdullah Behbahani and Mohammad Tabatabai, created a group that supported calling for majles and establishing a Constitution. Nuri expected that the document would do nothing else but organise sharia regulations in a brief and clear way. He had no doubts that the ulama would become social and political leaders in a situation when the Shah was unable to support the religious specificity of the culture and realization of the mission awaiting for Mahdi's coming. One should add that Nuri had been educated well enough to stand in the position of a moral and social leader: both his way of life and expressed views are evidence that Nuri was a devoted defender of a traditional, religious vision of reality. He had been a pupil of Mirza Hasan Shirazi (1815-1894), the author of the fatwa against the Tobacco Concession in 1890.

On the orders of his teacher, Mirza Hasan Shirazi, Nuri went to Tehran to follow the situation triggered by social discontent. After Mirza Ashtiyani had died, Nuri became one of the most influential clergymen in Teheran. Not only did he give lectures, propagate Islam and got engaged in political and social actions, but also made efforts to put fegh and sharia into practice.

\section{THE THESES}

Nuri's model of culture is coherent and complete; it presents a thorough vision of reality. These are features that make it highly attractive in the mashrute period, a time when historical events caused instability in the sociopolitical structure. This conclusion may be applied to other similar 
periods of crisis, such as the Islamic Revolution of 1979. The model gains its power from the existence of another antagonistic culture model which is perceived as unfamiliar and threatening. The idea of culture propagated by Nuri is also attractive as a utopia due to its simplicity and appeal to the emotions. As a complete model, the concept of the Islamic thinker is not a dialogical one; Nuri did not accept any discussion with his ideological opponents; instead, he focused on warning, instructing and giving advice.

\section{SEMANTIC ANALYSIS OF THE KEY WORDS WITHIN THE BACKGROUND OF THE MASHRUTE PERIOD}

The word qanun 'law' is the central term in Nuri's texts of the mashrute period. The history of its semantic transformation has its roots in the 1850s and was fully expressed in the newspaper Qanun, which was edited by Mirza Malkam Khan in London. Although the editor of Qanun referred to religion ("God blessed Iran, but his blessing was negated by the lack of $\left(\right.$ law" $\left.^{\prime \prime}\right)$, his vision of the legal order, one similar to that of another contemporary thinker Mirza Yousuf Khan Tabrizi Mostashar ad-Dowle, had its roots in the ideals of the European Enlightenment which were conceived after the French Revolution (1789). Its basis was founded upon the principle of equality of citizens in the eyes of the law; this law was created according to a social contract; it was the result of negotiations between various social groups and their interests. Nuri acted against these elements of law. He regarded himself as a religious leader for his community which, as a whole, constituted God's people whose final purpose was salvation. Nuri juxtaposed the law, given by God and based on the acceptance of God's will - eslam - with conceptions of law written by man. Nuri's reasoning was built on the basis of contradictions, namely: law created by human beings as opposed to one revealed by God; imperfect and incomplete law in contrast to that which is perfect and complete; law focused only on worldly matters to one which encompasses both the worldly and divine worlds.

For the community of believers it is obvious that God's law is the best one and this is an indisputable question. Thanks to God's mercy, we have the best

\footnotetext{
${ }^{4}$ Mirza Malkam Khan, Qanun, ed. by H. Nateq, Tehran 1976, p. 1.
} 
and the fullest divine laws; this is because it is the law which was revealed by the Lord of the World to His blessed messengers and prophets and the Last of His Prophets. ${ }^{5}$

Regarding the fact that the final goal of a Muslim's life is not to achieve happiness on earth but to conduct worldly matters in such a way as to be prepared for the afterlife, the splitting of the law into two parts is unjustified. The earthly order should be, for the believer, a time to become ready for the life beyond material reality and to attempt to live one's life according to perfect divine order. Nuri singles out the sphere of eternity as the answer regarding the final goal of culture and the meaning of human life. Hence, worldly life is not a purpose in itself. As a consequence, results are not immediately evident, which, in turn, suggests concentration on intentions which trigger actions.

We should desire to organize our worldly matters upon the foundation of Islamic faith in order not to spoil our divine matters. Certainly, only God's law is the right one; that is, because it is the one which encompasses both spheres, i.e. the order of this world and paradise. ${ }^{6}$

In the discussion about the origins of law, one notices the opposition of the Qur'an and Muslim tradition to the text of the Constitution, which is called by Nuri a "book of mistakes" (zalalatnameh). According to Nuri, the very notion of constitutional order had not been specified", which caused numerous occurrences of exploitation from those who had written the Fundamental Law (qanun-e asasi). As a result, the actions of the Persian parliament were not in accordance with these which the Qur'an provides for secular power, namely the protection of Islam and support for its promotion. Nuri tried to explain the semantics of the notion of

${ }^{5}$ F. Nuri, Ketāb-e tazkerāt al-qāfel va ershād al-gāhel, in: idem, Resa'el, elamiye-ha, maktubat, . . . va ruzname-ye Sheykh Shahid Fazlallah Nuri, ed. by M. Torkeman, Tehran 1983, p. 55. (Unless otherwise indicated, all quotations from Persian translated by M. Abassy).

${ }^{6}$ Ibid., p. 56.

7 “Az ānjā'i ke lafz-e mashruteh tā be hāl dar irān mosta'mel nabud va hāl gofte mishavad majles be qānun-e mashruteh raftār minamāyad va ma'ni-ye ān ma'lum nist ..." F. Nuri, Esteftā'-e pirāmun-e hodud-e majles-e showrā-ye melli be khatt-e Sheykh Shahid, in: idem, Maktubat, elamiye-ha, ... va chand gozaresh-e piramun-e naqsh, ed. by M. Torkeman, Tehran 1984, p. 65. 
parliament (majles) by certain descriptive definitions. In a letter to Ayatollah Musavi ${ }^{8}$, he writes that the majles was summoned thanks to the mercy of the Shah, but God's will initiated it as an outcome of martyrs' struggle, the moral greatness of the people and the dissemination of Islam. Majles is a manifestation of what had been carried out in the spiritual domain. Nuri stresses the fact that crucial historical events are not human deeds but the actions of God. A believer may only pray for mercy and stand ready to accept it. It is worth repeating this statement, one which is essential to the understanding of Nuri's idea of culture: God is the creator of all plans, while man is merely their humble contractor. In a telegram to clergymen in Najaf, Nuri defined the task of majles more precisely; he claimed that it had been summoned to

protect and set free the ordinary people from oppression of the high and mighty of this world and to create such circumstances to protect Islam from any weakness. ${ }^{9}$

Moreover, the issue of a plenipotentiary (vekalat) is not quite clear, either. Nuri asks why people are to choose their representatives if Islam gives the right of social leadership to the Prophet and His heirs.

Don't you know that in social matters a plenipotentiary is not necessary because the one who deserves it supports his plenipotentiary with the rank of sharia legate? Giving an opinion about matters concerning the community and the whole of mankind is proper for the Imam of Islam or his plenipotentiaries and has no relation to others, and any interference of outsiders is forbidden. ${ }^{10}$

According to Nuri, the plenipotentiary system is based on people who do not know fegh and this fact repudiates their competence to make decisions concerning the Muslim umma and the state. The mojtaheds' authority is based on the knowledge which has been passed from teacher to student since the time of the Prophet Muhammad and Ali. One should

${ }^{8}$ F. Nuri, Nāme-ye Sheykh Shahid be marhum-e Āyatullah Āqā Seyyed 'Ali Āyatullahi Musavi, in: idem, Maktubat, elamiye-ha, . . . va chand gozaresh-e piramun-e naqsh, ed. by M. Torkeman, Tehran 1984, p. 40.

${ }^{9}$ F. Nuri, Musude-ye telegrāf-e Shaykh Shahid va Jam'i az 'olamā' be Āqāyān-e Hajj-e Eslām-e Najaf-e Ashrāf, in: idem, Maktubat, elamiye-ha, . . . va chand gozaresh-e piramun-e naqsh, ed. by M. Torkeman, Tehran 1984, p. 44.

${ }^{10}$ F. Nuri, Ketāb-e tazkerāt . . ., op. cit., p. 67. 
notice that such continuity is unusual in any except the Muslim culture. ${ }^{11}$ Thus, the idea of giving ordinary people the right to choose representatives damages the very foundations of Islam.

... what is the meaning of a representative system (vikalat)? Who is the elector and what is the representative elected for? If the problem concerns secular affairs, there is no need for the religious arrangements. If general religious matters are to be treated, then these matters are related to vilayat (i.e. the rulership which is authorised by God through His Prophet and the Imams, that is to say, the ulama), not vikalat. During the (Greater) Occultation of the (Twelfth) Imam, may God hasten His happy ending, (i.e. His return), vilayat lays within the capacity (only) of the specialists in figh and of the mujtahids, not of a layman. ${ }^{12}$

Nuri takes the position of social elitism; he claims that a higher or lower place in the community relates to one's extent of knowledge of the Qur'an. These who are closest to reading God's idea: the learned people, mojtaheds are at the top of the hierarchy. By raising the question of social leadership of the Shia clergymen, the heirs of the Prophet and the guards of tradition, Nuri refers to the hierarchical social order with God at the summit. The place of a man within the social hierarchy, which determines specific rights and duties, is connected with the level of knowledge of fegh. This can never be an object for negotiation or a result of voting. The principle of equality before the law disturbs the hierarchical order. This is one of the reasons why Nuri acts against the principle of equality (mosavat).

The foundations of the Qur'an's rule are based on the difference of law of various people, and you swore by the Qur'an to act in accordance with the principle of equality. The Qur'an's rule was founded on the lack of freedom (azadi nabudan) for the press and speech; you swore to fight for their freedom. The Qur'an categorically condemns giving the right of revenge (qasas) and you swore you would support the right of compensation for the unbelievers. ${ }^{13}$

${ }^{11}$ Comp. М. Мотаххари, “Вклад Ирана в Исламскую цивилизацию”, Иран Наме, no. 1 (2008), p. 83.

${ }^{12}$ Quoted in A.H. Hairi, "Shaykh Fazl Allah Nuri's Refutation of the Idea of Constitutionalism", Middle Eastern Studies, XXIII.3 (1977), p. 328.

${ }^{13}$ F. Nuri, Ketāb-e tazkerāt . . ., op. cit., p. 95. 
Equality, as an idea, constitutes the most obvious proof that the rights contained in the text of the Fundamental Law are contradictory to the Qur'an. The realization of the suggestion to combine constitutionalism with sharia, as expressed by the statement mashrute ya'ni mashru'e is impossible. In Nuri's opinion it is not possible to combine religious and secular elements in order to form a stable basis for the vision of reality. They are incompatible. Nuri perceives the principle of equality as destructive for social order; he asks:

If their intention was to call into being the divine laws and the aim of constitutionalism was to protect the order of Islam, why then do they want to base its foundations on equality (mosavat) and freedom (horriyat), as each of these two principles is harmful and destructive for the basis of the order of divine laws? ${ }^{14}$

Subsequently, he explains that the people of Islam have to be obedient to God's commands and, by reference to them, they have to make decisions about who is equal and who is inferior to them. The issue of equality concerns not only relations between Muslims and non-Muslims but also family relations: a wife is not equal to a husband, nor a child to a parent, nor a pious but uneducated man to a mojtahed, etc. Regarding the fact that one's position in a social hierarchy determines specific rights, it is not difficult to imagine what chaos would occur if the balance of the wellordered system was disturbed by implementing the principle of equality. In the light of the Fundamental Law, the social bonds which are based on the patriarchal order are negated. The religious community, united by God's law, is transformed into a mechanical set of individuals who are focused on worldly matters. In the background of Nuri's considerations, the opposition of the divine order to the satanic concept of reality occurs.

After they finished (the business of) establishing innovations and compiling misleading remarks (the constitution), they began to take actions. They performed what they performed implementing obscenities, reprehensible actions, insulting Islam, distorting (its) provisions, degrading the divine ulama, violating the sharia and religion, enjoying indecency and forbidding right conduct, gathering together the false and making propaganda among the erroneous and ignorant. (They also) denied respect for the Book of God, (created

${ }^{14}$ Ibid., p. 59. 
satanic) temptations in the minds of the common people about the elevation of cult practices (ordered by God), they shed blood and put (their innovative) ideas into operation. ${ }^{15}$

The principle of freedom (horriyat), mentioned in Nuri's writings, is also contradictory to the principle of submission to God's will (eslam). The juxtaposition of azadi and eslam is a reference to the anthropocentric and theocentric visions of the world.

Nuri inquired as to the semantics of the notions of qanun, mosavat, horriyat (azadi) and mashrute in discussions during the time of bast in Abdolazim mosque and in conversations with representatives of the British embassy. He did not read European texts nor did he ever visit Western Europe or Russia. Pointing to Russia and the Ottoman Empire, as sources of the ideas which had come to Iran, Nuri, in a naïve but accurate way, associated constitutionalism with the secularization of culture. The fact that Turkey had managed to combine Islam and European elements was not an argument which could convince Nuri that it would be possible to combine sharia law with the clauses of the Fundamental Law. He regarded the constitution as a "book of mistakes", because it falsified the meaning of law and implemented innovations that would lead not to strengthening, but to weakening Islam.

The model of culture presented in Nuri's writings assumes one's submission to God's will (eslam) and a return to the time of perfect justice. Muslim culture is situated beyond space and time, in the eternal world. Earthly existence is merely a time of preparation to pass to that metaphysical dimension. Time is not linear but cyclical; the progress of mankind is not regarded as limitless but it is regarded as a return to an initial state of justice and harmony.

\section{CONCLUSIONS}

Nuri regarded the qualities derived from Islam as familiar and as his own and emphasised them by creating an opposing, threatening model of "the other". Historical circumstances helped Nuri's model to gain power. Without such a specific situation created by the struggle for (and against)

${ }^{15}$ Quoted in A.H. Hairi, "Shaykh Fazl . . .", op. cit., p. 331. 
the constitution, this model would not have emerged in such a coherent shape. Nuri presented a model which is static. Its borders are closed, elements from outside are not allowed to enter the system. Moreover, any development of the system is impossible and it will eventually become petrified. Real or imagined danger caused the radicalization of all elements within the model, including a call for the physical extermination of the representatives of "the other" model.

\section{NURI'S PERSONALITY AND IDEA FROM HISTORICAL PERSPECTIVE}

There are many contradictory views towards Nuri's conduct during the struggle for the Constitution in Iran. Some scholars regarded him as a defender of Islam whereas others claimed that religion for Nuri was nothing more but a tool to gain particular benefits. Baqer Mo'ameni refers to the content of the mashrute period's newspapers and the information that Nuri accepted a bribe from Ejn ad-Doule, one of the Shah's ministers. ${ }^{16}$ Nazem al-Eslam Kermani reminds us that Nuri had asked the prime minister, Amin as-Soltan, for 12,000 tumans for religious purposes and, after the request had been rejected, started manifesting his support for Behbahani - then a proponent of the constitutional movement. ${ }^{17}$ Ahmad Kasravi, in turn, claims that every step of Nuri's was motivated by the clergyman's religious enthusiasm and the desire to create a state based on sharia law. ${ }^{18}$

Nuri's conduct is sometimes juxtaposed with that of Behbahani and Tabatabai. Thus, the first is presented as a conservative, fundamentalistically motivated ulema whereas the two others are regarded as proponents of the constitutional order in Iran. Nuri commented on it thus:

Neither I was an absolutist nor were seyyeds Behbahani and Tabatabai the constitutionalists. Simply, I was against them and they were against me. ${ }^{19}$

\footnotetext{
${ }^{16}$ B. Mo'ameni, Din va doulat dar asr-e mashrutiyat, Stockholm 1998, p. 159.

${ }^{17}$ A.H. Hairi, "Shaykh Fazl . ..", op. cit., p. 209.

${ }^{18}$ A. Kasravi, Tarikh-e mashrute, Tehran 1346 (1967), p. 287.

${ }^{19} \mathrm{~F}$. Adamiyat, Ideologi-ye nohzat-e mashrutiyat-e Iran, Tehran 1355 (1976), pp.
} 429-430. 
After Teheran was occupied by the Bakhtiar army, Nuri was imprisoned and accused of betrayal of the mashrute. Having been given the choice either to reject in public his previous opinion or to be sentenced to death, Nuri chose the second option. Nazem al-Eslam wrote that when Nuri was approaching the gallows, he said: "I'm coming. Khoda hafez" and was answered: "Go to hell!" 20 Mehdi Sharif Kashani, a member of a group associated with Ayatollah Behbahani, wrote about the day of the execution as follows:

The whole square was crowded with people. They vehemently applauded and, full of joy, watched the execution. ${ }^{21}$

This observation was confirmed by Nuri's friends:

The people applauded and blasphemed. Great uproar fulfilled Tupchane square. When the body was taken from the gallows to the Nezamiye yard, there followed general confusion. Everybody who had anything in their hands hit the body and those who had no tool spat upon it. ${ }^{22}$

A question arises regarding the reasons for such fierce hatred towards a man who was a religious authority, a respected and eminent person. The turbulent time of the mashrute period brought about disturbances, bloodshed and general uncertainty about the future. Ordinary people, who were only superficially aware of events, blamed Nuri for past misfortunes. Moreover, the model propagated by Nuri was not popular on the threshold of the $20^{\text {th }}$ century. It was rather in the background of such ideas as liberalism, democracy, constitutionalism, codified law etc. As most eminent mojtaheds had allied themselves with the secular intelligentsia, Nuri's idea seemed to be a little bit obscure.

Nevertheless, both Nuri's life and death has had far-reaching consequences.

\footnotetext{
${ }^{20}$ N. al-E. Kermani, Tarikh-e bidari-ye Iran, Tehran 1357 (1978), p. 535.

${ }^{21}$ Ibid., p. 163.

22 Ibid.
} 


\section{CULTURAL IDENTITY OF IRAN IN THE LIGHT OF NURI'S VALUES}

After a certain time, the Nuri's body became a symbol of the defence of Islam. It also started being interpreted as a great mistake to kill a mojtahed in the name of values totally disconnected from Islam. Mo'ameni commented on this fact as follows:

The people were surprised by the public execution and, at the same time, they were given an object lesson how to hang a mojtahed. . . . The people, schemers and clergymen say that it would have been better to kill the sheikh in secret. ${ }^{23}$

Many years after the event, Jalal al-e Ahmad, the author of a popular book Weststruckness (Qharbzadegi) ${ }^{24}$, called Nuri a defender of Shia Islam's integrity against the poisoning of it with Western influence:

For me, the body of the eminent man, hanging from the gallows was like a signal flag of west-poisoning over the roofs of our houses, after a two-hundredyear struggle. . . . Now, in the shadow cast by that flag we, as a nation, are alien to ourselves; regarding our clothes, food, literature and - what's even more dangerous - culture. We follow the Western education, we surrender to the Western thinking and we use the Western ways to solve our problems. ${ }^{25}$

Contrary to the opinion of most scholars who claim that the conflict among clergymen, between the proponents and opponents of the constitutional movement, was due to the struggle for political power, we claim that the conflict had cultural roots and Nuri was the first who recognised the core danger. The temporary alliance between Nuri and the Shah's court against mashrute is not surprising: both Islam and autocracy belonged to the traditional cultural values and, as such, supported each other against something they perceived as an alien cultural influence.

Thus, ideological differences between the proponents and the opponents of the mashrute movement were the consequence of a cultural split, not the reason for it.

Subsequently, Nuri's idea of culture won out in 1979 and became the basis for contemporary Iran.

\footnotetext{
${ }^{23}$ Ibid., p. 173.

${ }^{24} \mathrm{~J}$. al-e Ahmad, Weststruckness (Qharbzadegi), Tehran 1341 (1963).

${ }^{25}$ Ibid., p. 78.
} 


\section{BIBLIOGRAPHY}

Primary sources:

al-e Ahmad J., Weststruckness (Qharbzadegi), Tehran 1341 (1963).

Fazlallah N., Resa'el, elamiye-ha, maktubat, . . va ruzname-ye Sheykh Shahid Fazlallah Nuri, ed. by M. Torkeman, Tehran 1983.

Fazlallah N., Maktubat, elamiye-ha, . . va chand gozaresh-e piramun-e naqsh, ed. by M. Torkeman, Tehran 1984.

Hairi A.H., "Shaykh Fazl Allah Nuri's Refutation of the Idea of Constitutionalism", Middle Eastern Studies, XXIII.3 (1977), pp. 327-339.

Mirza Malkam Khan, Qanun, ed. by H. Nateq, Tehran 1976.

Mirza Jusuf Khan Tabrizi Mostashar ad-Dowle, Resale mowsum be yek kaleme, ed. by A.R. Dowlatshahi, Tehran 2007.

Secondary sources:

Adamiyat F., Ideologi-ye nohzat-e mashrutiyat-e Iran, Tehran 1355 (1976).

Afary J., The Iranian Constitutional Revolution 1906-1911, Columbia 2005.

Browne E., The Persian Revolution of 1905-1909, Cambridge 1910.

Kasravi A., Tarikh-e mashrute, Tehran 1346 (1967).

Kermani N. al-E., Tarikh-e bidari-ye Iran, Tehran 1357 (1978).

Mo'ameni B., Din va doulat dar asr-e mashrutiyat, Stockholm 1998.

Ridgeon L. (ed.), Religion and Politics in Modern Iran, London - New York 2005.

Rosner K., Semiotyka strukturalna w badaniach nad literaturq, Kraków 1981.

Salehi N., Andishe-ye tajaddod va taraqqi dar asr-e bahran, Teheran 1387 (2008). 